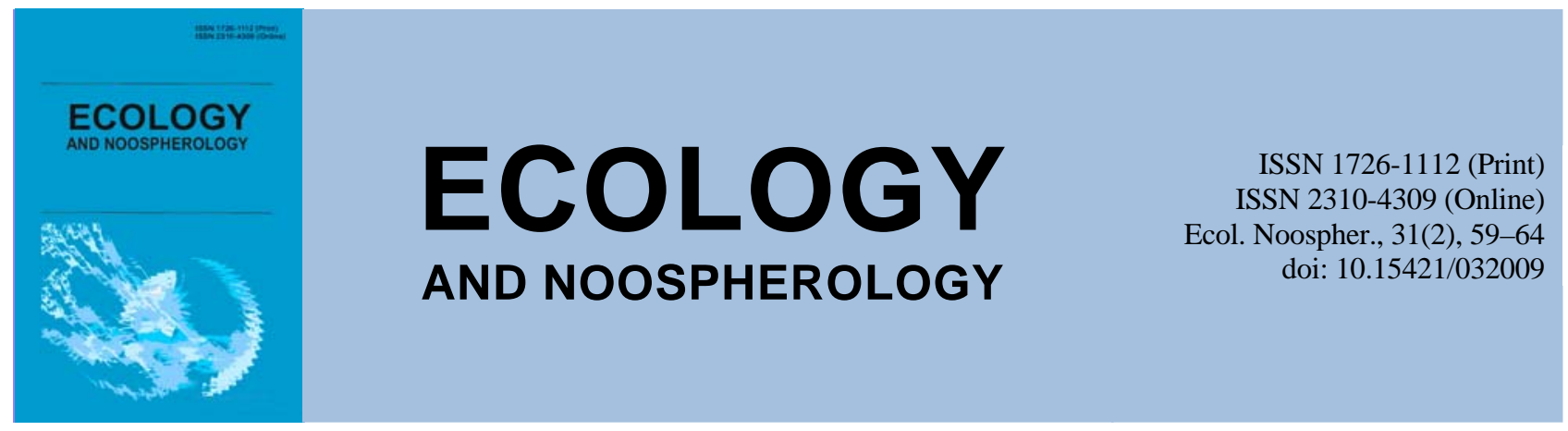

\title{
Palaeoecological aspects of an Ukrainian Upper Holocene chernozem
}

\author{
J. M. Recio Espejo*, O. V. Kotovych**, F. Díaz del Olmo***,V. A. Gorban**, \\ R. Cámara Artigas***, O. M. Masyuk**, C. Borja Barrera*** \\ *University of Cordoba, Cordoba, Spain \\ **Oles Honchar Dnipro National University, Dnipro, Ukraine \\ ***University of Seville, Seville, Spain
}

Article info

Received 15.04.2020

Received in revised form 23.04.2020

Accepted 29.04.2020

University of Córdoba, Campus de Rabanales, 14001-Córdoba, Spain.

Tel.: +003495-721-85-97

E-mail:bv1reesj@uco.es

Oles Honchar Dnipro

National University,

Gagarin Ave., 72, Dnipro, 49010, Ukraine.

University of Seville, Maria de Padilla, 41004-Sevilla, Spain.
Recio Espejo, J. M., Kotovych, O. V., Díaz del Olmo, F., Gorban, V. A., Cámara Artigas, R., Masyuk, O. M., Borja Barrera, C. (2020). Palaeoecological aspects of an Ukrainian Upper Holocene chernozems. Ecology and Noospherology, 31(2), 59-64. doi:10.15421/032009

A physicochemical, palynological and chronological analysis of a soil profile corresponding to a Haplic Chernozem (FAO, 2015) developed in the Ukrainian steppe allow the interpretation of recent environmental changes that have conditioned its formation. Uniformed under the blackening process, its surface horizon dark color contrasts with yellowish color loessic parental material; it is decarbonated and the organic carbon content on the surface is $2.24 \%$.The texture is silty in surface but sandy in lower horizon denoting a clear wind selection and an energy change in aeolian sedimentation processes. The clays present similar values in the three analyzed horizons. The presence of two discontinuities in the profile has made it possible to distinguish a very sandy blackened horizon of $2500+/-25$ cal BP chronologies from another silty surface and black chromas of age 1336-1256 cal BP. A total of fifteen pollen types have been identified; superficial horizon (A11) has a high presence of pollen of the Amaranthaceae type, the Poaceae are the most abundant and Quercus gender is identified. The sandy horizon (2A/B) shows Poaceas, Pinus, and Oleaceas presence together pollen of Rosaceas type (14\%). Pollen data reveal vegetative changes in the three horizons with the presence of even non-existent species today, linked both to recent anthropicclimatic and holocene-type changes on a millennial scale since the last glacial period.

Keywords: steppe; Ukrainian chernozem; palaeoecology

\section{Introduction}

The present work represents a contribution to the research line maintained by the authors in relationship to the ecological factors and geomorphological conditions that motivate the blackening and tirsification processes of some pedological horizons of Vertisols, Chernozems or chilean Andosols (Núñez et al., 1997; Recio et al., 2017, 2018, 2019, a, b; Guajardo et al., 2020). The study of a polyphasic profile corresponding to a Calcic Chernozem (FAO, 2015) has allowed us to deepen this process as well as to evaluate some of the palaeocological conditions that have controlled its formation (Alexandrovskiy and Chichagova, 1998; Khokhlova and Kovalevskaya, 2001).

This soil profile (Calcic Chernozem) (FAO, 2015) studied by the authors (Fig. 1) are located to coordenates position $48^{\circ} 45^{\prime} 36.9^{\prime \prime} \mathrm{N}, 35^{\circ} 27^{\prime} 40.5^{\prime \prime} \mathrm{E}$ within the virgin steppe land of watershed plateau in a culminating position (south-eastern part of the Andreevka village).

The current majority vegetation support by the superficial horizon is constituted by Festuca valesiaca Schleich former Gaudin, (Poaceae), Koeleria macrantha (Ledeb.) Schult (Poaceae), Thymus marschallinus Wilid. (Lamiaceae), Linum hirsutum L. (Linaceae), Salvia nemorosa L. (Lamiaceae), Austrian Artemisia Jacq (Asteraceae).

\section{Material and methods}

For its morphological and physicochemical characterization have been used the guide FAO (1977), the colour parameters was determined by Munsell (1990), carbonates (Duchaufour, 1975), wet and ignition loss by M.A.P.A (1986), total organic carbon by Sims and Haby (1971), magnetic susceptibility (Dearing, 1999) and textural analysis and distribution particle size by Soil Survey England and Wales (1982) (Table 1, 2, 3, Fig. 1).

From this profile the pollen present on the horizons (A11, $0-20 \mathrm{~cm}$ ) and lower zone profile $(2 \mathrm{~A} / \mathrm{B}$ and $3 \mathrm{BC} 1)$ has been identified following the method described by Dupré Olivier (1979), with some modifications proposed by Martín Consuegra (1996) and by López et al. (2003). With the pollen extracted, its identification has been carried out under optical microscopy through the use of the reference palinoteca and different pollen atlases (Table 3).

Chronological dating by $\mathrm{C}_{14}$ cal. $\mathrm{BP}$ was performed in the humine fraction of the superficial horizon (A11) by the Beta Analytic Laboratory (Miami, Florida, USA) and the medium horizon (2A/B) by the Accelerator National Centre of CSICUniversity of Seville (Seville, Spain) (Fig. 2). 


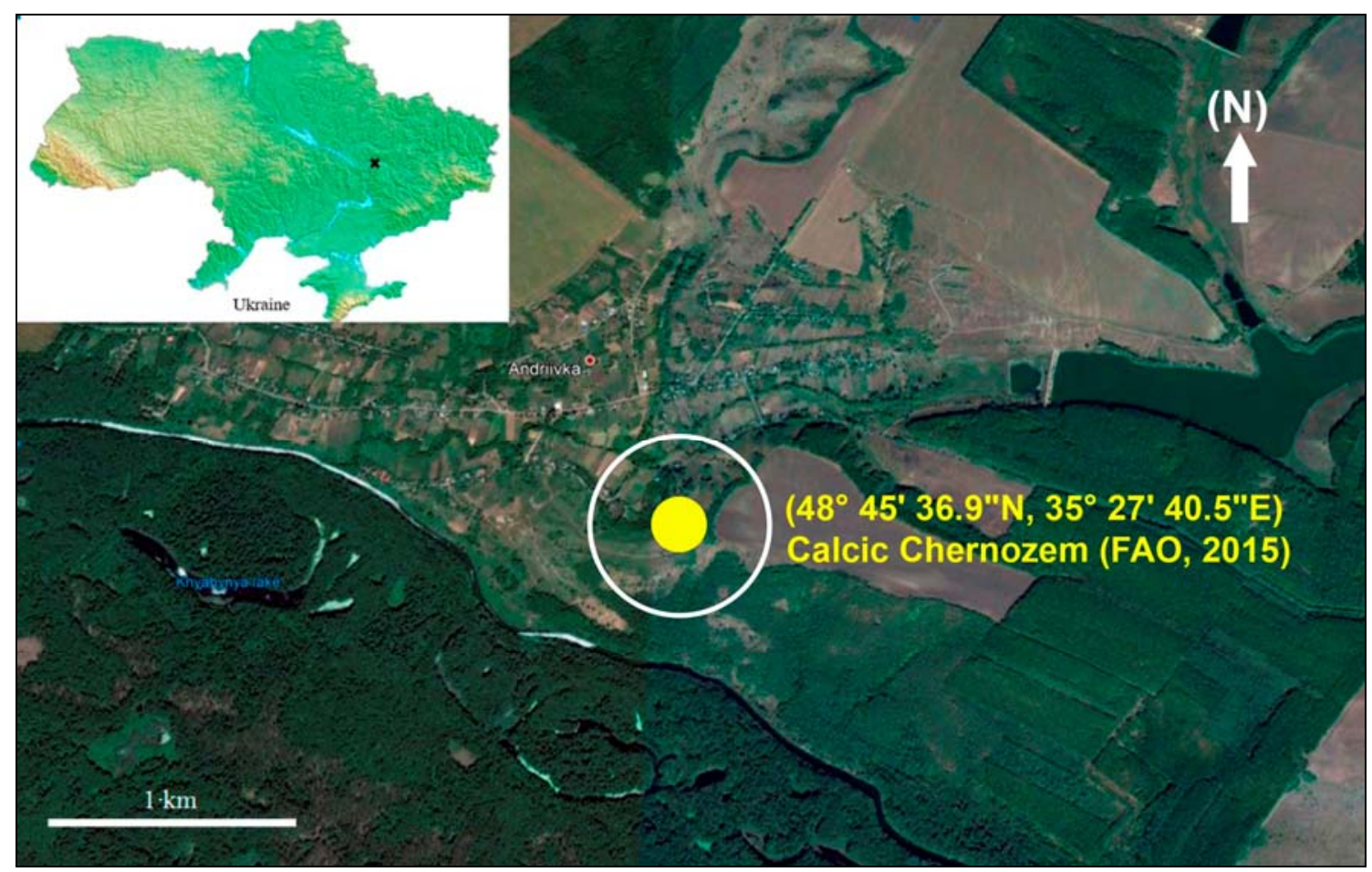

Fig. 1. Location of studied area

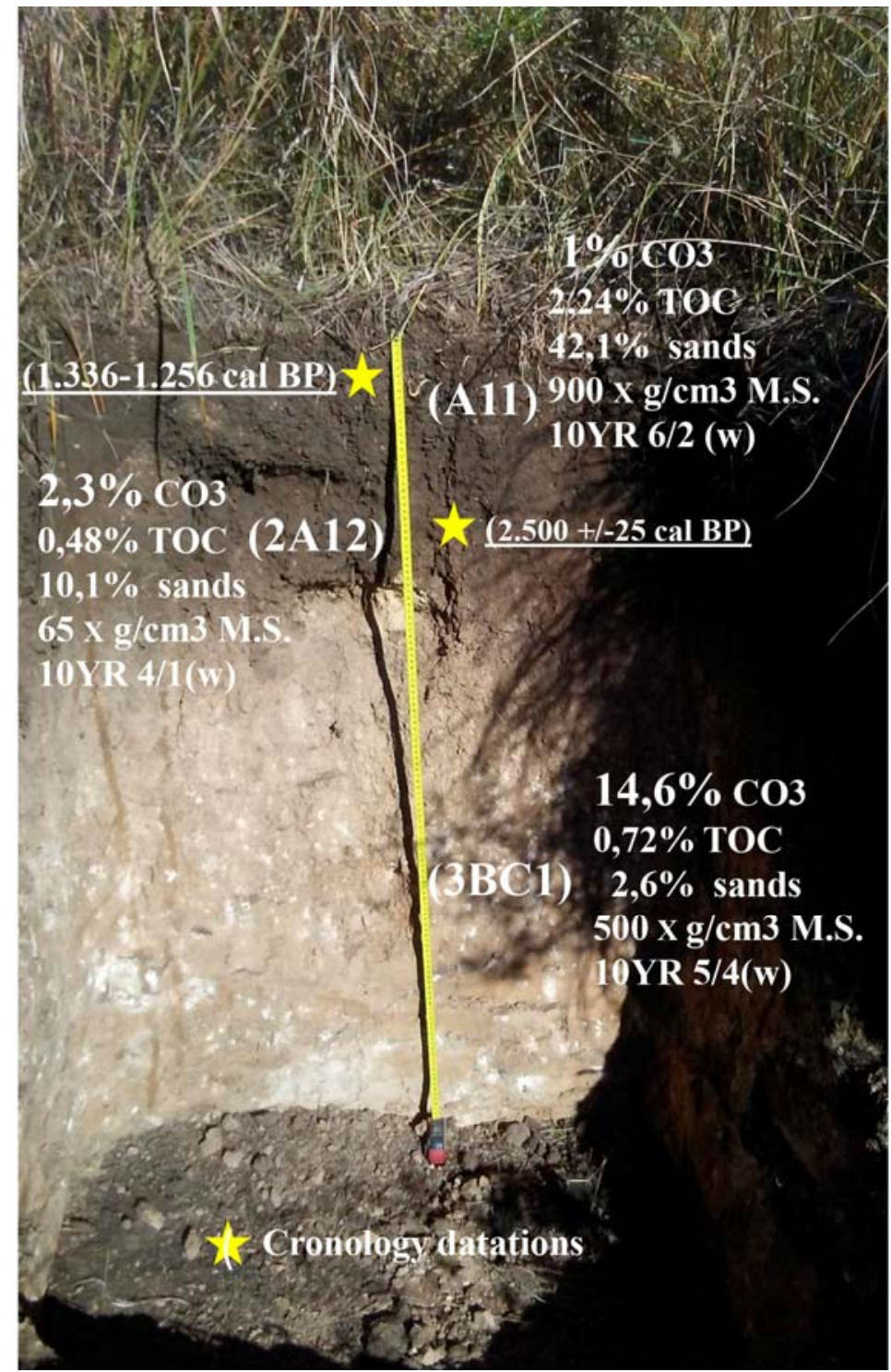

Fig. 2. Haplic Chernozem (FAO, 2015) 


\section{Results and discussion}

Table 1 shows the physical-chemical characterization carried out in the profile. The dark color of the surface horizon (10YR 4/1) contrasts sharply with the yellowish tones of the parental loess (10YR $7 / 4$ ), at $130 \mathrm{~cm}$ from the surface, and equally affects the two surface horizons (A11 and 2A/B), uniformed under the blackening process.

The organic carbon content on the surface is $2.24 \%$, and at $80 \mathrm{~cm}$ depth (3BC1) it becomes $0.72 \%$, greater than in the overlying horizon. The loss on ignition is $7.88 \%$ on the surface, so we can consider that $49 \%$ of it is humidified, compared to $20 \%$ in $2 \mathrm{~A} / \mathrm{B}$ and $35 \%$ in $3 \mathrm{BC} 1$ respectively (Table 1 ).

It is decarbonated, these being accumulated in the form of powdery spots on the 3BC1 horizon (14.6\%). Magnetic susceptibility values are low, highlighting those found in 2A12 much lower than the rest of the horizons. In relation to the density and porosity that the horizons present, coincide with the values previously found by Nuñez et al. (1997) and very different from those presented by blackening horizons Andosol (FAO, 2015) studied by Guajardo et al. (2020) and developed on yellowish ash of volcanic origin.

Its texture is silty except in the 2A12 horizon where the sand fraction is the dominant one with $42.1 \%$ and where very thick fractions are represented (Table 2). In the superficial horizons, the dominant sand fraction is that of diameter 0.25$0.125 \mathrm{~mm}$. denoting a clear wind selection. On the contrary, the 3BC1 horizon shows a loamier character, with a dominant fraction $(74 \%)$ in the fraction with the smallest diameter $(0.125-0.063 \mathrm{~mm}$. In this silt fraction, the largest fractions ( 0.063 to $0.015 \mathrm{~mm}$ ) are always the most representative (Table 2), denoting their wind selection. The clays present values around $40 \%$ in the three analyzed horizons (Table 1).

Another hand a total of 15 pollen types has been identified. The quantity has been expressed in pollen grains per gram of soil horizon (Table 1). Superficial horizon A11 $(0-20 \mathrm{~cm})$ has a high concentration with 473 pollen grains per gram, 45 are in 2A/B, while BC1 $(40-130 \mathrm{~cm})$ has 64 pollen grains per gram (Table 3 ). The $2 \mathrm{~A} / \mathrm{B}$ horizon presents only 4 pollen types, compared to 12 of the other horizons.

Table 3

Type polinics and its frequency in the different horizons

\begin{tabular}{|c|c|c|c|}
\hline $\begin{array}{l}\text { Type polinics (\%)/ } \\
\text { Horizons }\end{array}$ & A11 & 2A/B & 3BC1 \\
\hline Corylus & $2.33(\mathrm{O})$ & $0.00(-)$ & $8.57(\mathrm{~F})$ \\
\hline Pinus & $3.72(\mathrm{O})$ & $14.29(\mathrm{C})$ & $5.71(\mathrm{~F})$ \\
\hline Oleaceae & $3.26(\mathrm{O})$ & $14.29 \mathrm{C})$ & $11.43(\mathrm{C})$ \\
\hline Myrtaceae & $0.00(-)$ & $0.00(-)$ & $2.86(\mathrm{O})$ \\
\hline Cupressaceae & $0.00(-)$ & $0.00(-)$ & $2.86(\mathrm{O})$ \\
\hline Castanea & $0.93(\mathrm{R})$ & $0.00(-)$ & $8.57(\mathrm{~F})$ \\
\hline Quercus & $10.70(\mathrm{C})$ & $0.00(-)$ & $20.00(\mathrm{C})$ \\
\hline Poaceae & $16.28(\mathrm{C})$ & $57.14(\mathrm{~A})$ & $5.71(\mathrm{~F})$ \\
\hline Amaranthaceae & 55.81(A) & $0.00(-)$ & $11.43(\mathrm{C})$ \\
\hline Urticaceae & $1.40(\mathrm{O})$ & $0.00(-)$ & $2.86(0)$ \\
\hline Echium & $2.33(\mathrm{O})$ & $0.00(-)$ & $2.86(\mathrm{O})$ \\
\hline Apiaceae & $1.40(\mathrm{O})$ & $0.00(-)$ & $0.00(-)$ \\
\hline Salix & $0.47(\mathrm{R})$ & $0.00(-)$ & $0.00(-)$ \\
\hline Rossacea & $0.00(-)$ & $14.29(\mathrm{C})$ & $0.00(-)$ \\
\hline Compositae & $0.93(\mathrm{R})$ & $0.00(-)$ & $5.71(\mathrm{~F})$ \\
\hline No determinated & 0.47 & 0.00 & 11.43 \\
\hline Types polinic & 12 & 4 & 12 \\
\hline Grains by sample grams & 473 & 45 & 64 \\
\hline Abundant & \multicolumn{3}{|c|}{$>25.0 \%(\mathrm{~A})$} \\
\hline Common & \multicolumn{3}{|c|}{$10.1-25.0(\mathrm{C})$} \\
\hline Frequent & \multicolumn{3}{|c|}{$5.1-10.0(\mathrm{~F})$} \\
\hline Occasional & \multicolumn{3}{|c|}{$1.1-5.0(\mathrm{O})$} \\
\hline Rare & \multicolumn{3}{|c|}{$0.3-1.0(\mathrm{R})$} \\
\hline Very rare & \multicolumn{3}{|c|}{$<0.3 \%$ (VR) } \\
\hline Absent & \multicolumn{3}{|c|}{$(-)$} \\
\hline
\end{tabular}

Note the high presence of pollen of the Amaranthaceae type followed by Poaceae on the surface horizon with values of $55 \%$ (A, abundant) and $16 \%$ (C, commont) respectively. The Quercus gender is also represented (10\%) in both horizons with a common character (C). The 3BC1 sample has a lower concentration of pollen grains and its largest representative is Quercus (C) followed by Amaranthaceae and Oleaceae. (F, frequent and $\mathrm{C}$, common). In this deepest level the grains of pollen from cherries are the best represented, presenting two pollen types not present in the previous one (Myrtaceae and Cupressaceae) with an occasional (O) frecuency (2.86\%).

The intermediate sandy horizon shows, like the others, the presence of Poaceas, Pinus, and Oleaceas, and pollen belonging to the Rosaceas family $14 \%$ (C) are only represented here. The majority vegetation supported by the current soil superficial horizont is Poaceae; some specific genders determinates are not currently represented in the area.

In view of these results, there seems to be a clear disagreement in the profile linked to an energy change in eolian sedimentation processes. Erosive-sedimentary processes of a sandy nature have come to interrupt the initial and final siltloessic sedimentation processes found in the profile, and which have shaped changes in the starting parental material linked to anthropization (agricultural erosion) or to environmental humidity-aridity changes related to Bond cycles (Bond et al., 1997). This palaeoenvironmental conditions and the profile chronology obtained may suggest this formation under the influence of millennial-scale climate cycles. The dating has revealed a chronology of 1336-1256 cal BP to horizon upper silty superficial horizon (A11), and $2500+/-25$ cal BP for the middle horizon (2A12) developed on sandy parental material (Fig. 3).

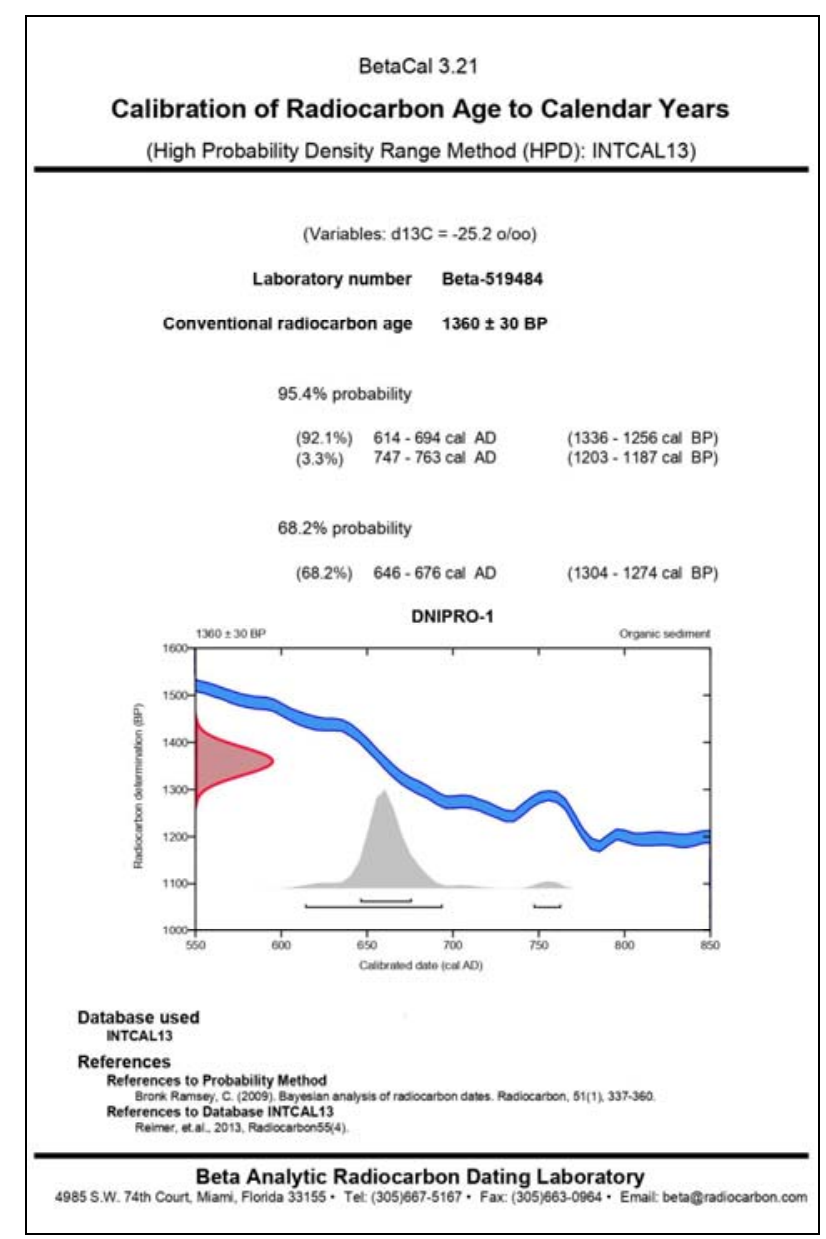

Fig. 3. Chronology dating 

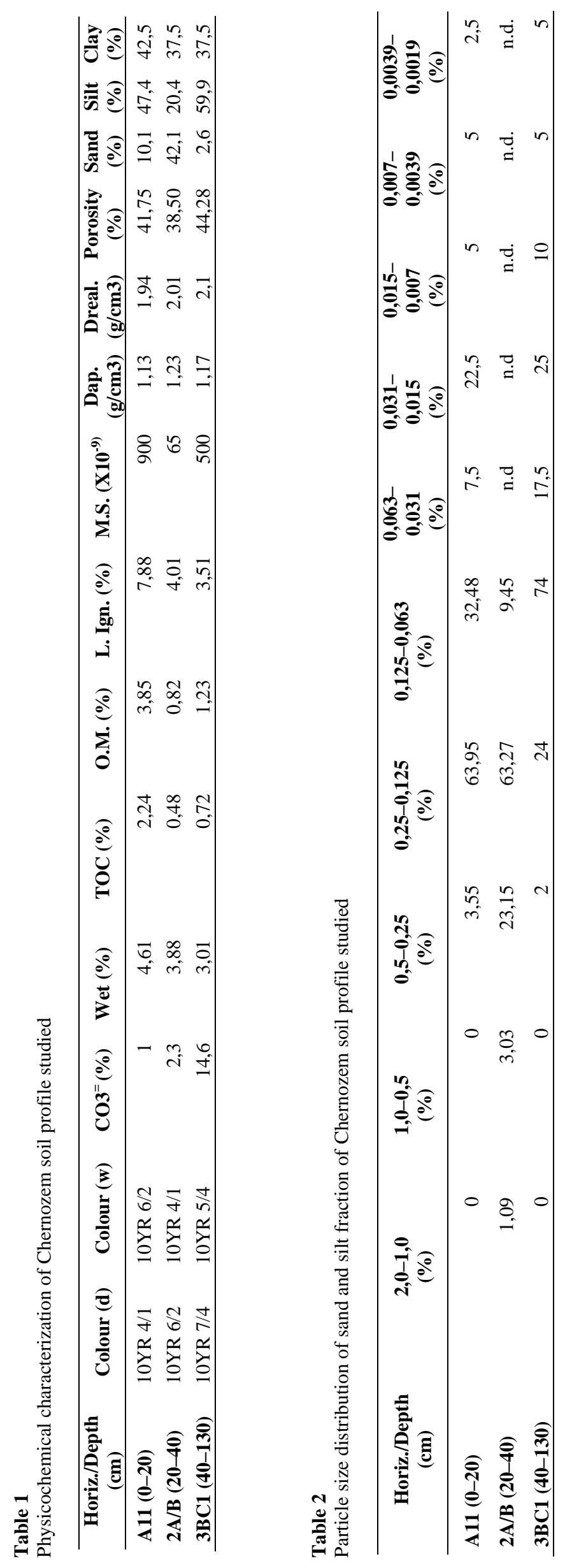
To explain the vegetation climate changes with the initial deepest horizon, we could use the Types of Bioclimatic Regimes of Cámara (2004) applied in other geographic regions (Cámara et al., 2005) from the Worldclim climate database (Hijmans et al., 2005). The change from dry- subhumid mesocryo-mesophylle conditions (16) with the presence of pines and deciduous forests towards the current subhumid-dry and semiarid cryo-mesophylle conditions (7 and 8) corresponding to the steppe could explain the presence of some of the pollen types found (Fig. 4).
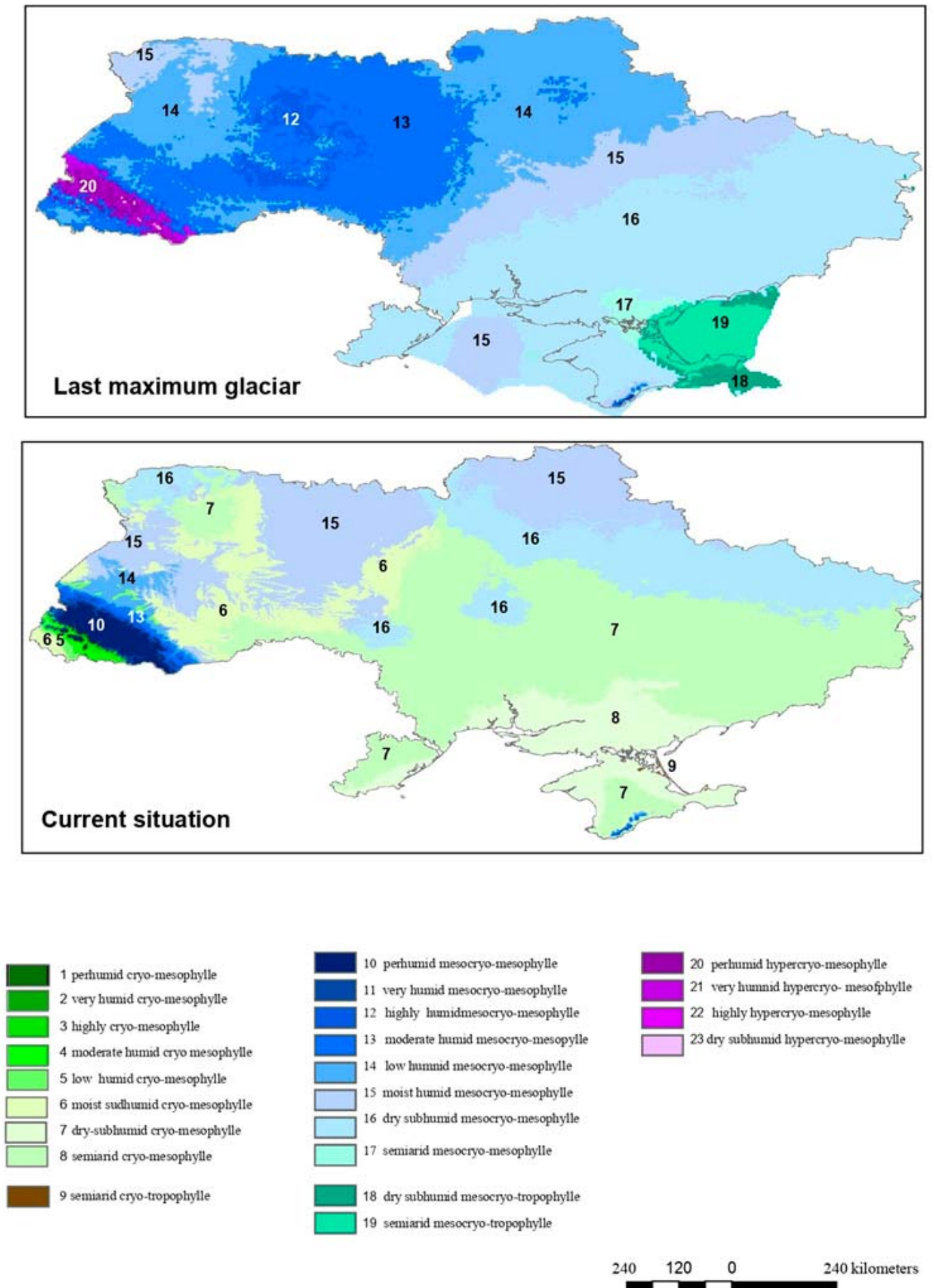

Fig. 4. Types of bioclimatic regimen changes zones (Cámara, 2004) from climate data base wordclim (Hijmans et al., 2005)

\section{Conclusions}

The blackening process that affects the upper part of the profile studied comes to mask the presence of two very different horizons formed under different environmental conditions. As a consequence of these erosive phases, the pedogenesis that affects the initial parental loessic material appears independent of that of these higher horizons. These changes have occurred on a historical scale with ecological significance for the last 2500 years BP derived from anthropogenic and/or climatic action with the presence of different species from those currently present. 


\section{References}

Alexandrovskiy, A. L., Chichagova, O. A. (1998). Radiocarbon age of Holocene paleosols of the East European foreststeppe zone. Catena, 34, 197-207.

Bond, G., Showers, W., Cheseby, M., Lotti, R., Almasi, P., Demenocal, P., Priore, P., Cullen, H., Hajdas, I., Bonani, G. (1997). A Pervasive Millennial-Scale Cycle in North Atlantic Holocene and Glacial Climates. Science, 278, 1257-1266.

Cámara, R. (2004). Escalonamiento bioclimático, regímenes ecodinámicos y formaciones vegetales de la Isla de La Española en República Dominicana. Estudios en Biogeografía 2004. Terrassa, España. Publications of Universitat Girona, 39-58 (in Spanish).

Cámara, R., Martínez, J. R., Díaz del Olmo, F. (2005). Desarrollo sostenible y Medio Ambiente en República Dominicana. Medios Naturales, manejo histórico, conservación y protección. Escuela de Estudios HispanoAmericanos (CSIC) y Universidad de Sevilla. Madrid, 280 pp. (in Spanish).

Dearing, J. A. (1999). Environmental magnetic susceptibility: using the Bartington MS2 system 2nd. Edi. Chi. Publ. Kenilworth, United Kingdom.

Duchaufour, Ph. (1975). Edafología. Edit. Toray-Masson. Barcelona, $476 \mathrm{pp}$.

Dupré Olivier, M. (1979). Breve manual de análisis polínico. Instituto Juan Sebastián Elcano CSIC, Valencia (in Spanish).

FAO (1977). Guía para la descripción de perfiles de suelo. Food and Agriculture Organization of the United Nations. Roma, 70 pp. (in Spanish).

FAO (2015). World reference base for soil resource 2014. International soil classification system for naming soils creating legends for soil maps. Food and Agriculture Organization of the United Nations. Roma, 193 pp.

Guajardo, C. H., Recio Espejo, J. M., Sandoval, M., Diaz del Olmo, F., Bustamente, M., Garcia-Ferrer, A. (2020). Anthropogenic alteration of available, amorphous and total iron in an Andisol by dairy slurry applications over a 12year period. Chilean Journal of Agricultural Research, 80, 108-117.

Hijmans, R. J., Cameron, S. E., Parra, J. L., Jones, P. G., Jarvis, A. (2005). Very high resolution interpolated climate surfaces for global land areas. International Journal of Climatology, 25, 1965-1978.
Khokhlova, O. S., Kovalevskaya, I. S. (2001). Records of climate changes in the carbonate profiles of Russian Chernozems. Catena, 43, 203-215.

López-Sáez, J. A., López García, P., Burjachs, F. (2003). Arqueopalinología: síntesis crítica. Polen, 12, 5-35.

M.A.P.A. (1986). Métodos de análisis del Ministerio de Agricultura, Pesca y Alimentación. Public. Secretaría General Técnica. Madrid (in Spanish).

Martín-Consuegra, E. (1996). Arqueopalinología y etnobotánica. Monografías del Real Jardín Botánico de Córdoba, 3, 23-31 (in Spanish).

Munsell, C. (1990). Munsell Soil Color Charts. Koll Morgen Instrument Corporation. Maryland (EE. UU.).

Nuñez Granados, M. A., Dueñas Lopez, M. A., Perevoznick, I., Recio Espejo, J. M. (1997). Un estudio comparativo entre Tierras Negras Andaluzas y Chernozems ucranianos. Cuaternario Ibérico, 355-359 (in Spanish).

Recio Espejo, J. M., Kotovich, A., Masyuk, A., Gorban, V., Díaz del Olmo, F. (2018). A comparative study of ukranian chernozems, chilean andosols and andalusian black earth. Ecological studies of forest ecosystems of the steppe zone of Ukraine: Extended Abstracts. International Conference, Ukraine, Dnipro, 71.

Recio Espejo, J. M., Sandoval, M., Borja, C., Díaz, F., Ubera, J. L. (2017). Characterization of tirsification soil weathering processes: The case of Los Lirios wetland, Guadalquivir basin, Seville, Spain. Chilean Journal Agricultural Research, 77, 406-412.

Recio, J. M., Kotovich, A., Diaz del Olmo, F., Gorban, V., Masyuk, A., Camara, R. (2019a). About the palaeoecological significance of Ukrainian Chernozems. Proceeding of the International scientific-practical conference dedicated to the 90th anniversary of the birth of Professor A. P. Travleev. 20-23.

Recio Espejo, J. M., Diaz del Olmo, F., Serrano Espinosa, A., Borja Barrera, C. (2019b). Determinant physical-chemical parameters for the black color in tirsification processes. Proceeding of the International scientific-practical conference dedicated to the 90th anniversary of the birth of Professor A. P. Travleev. 18-19.

Sims, J. R., Haby,V. A. (1971). Simplied colorimetric determination of soil organic matter. Soil Sci, CXII, 137-141.

Soil Survey England and Wales (1982). Soil Survey laboratory methods. Technical monographs $\mathrm{n}^{\circ} 6$. Harpenden (England). 83 pp. 